\title{
Effect of HRM Practices on the Performance of Companies Listed on NSE
}

\author{
M. A. Diriye, P. K'Obonyo, M. Munjuri, and G. Wainaina
}

\section{ABSTRACT}

The human resource function can make a crucial contribution in developing the key competencies in the institutions and individual employees that lead to high performance. The human resource configurations effectiveness is affected by the weak social capital among most organizations in Kenya, as evidenced by a lack of knowledge sharing and knowledge hoarding. The study's main objective was to see how HRM practices influenced the performance of firms listed on the Nairobi Securities Exchange (NSE). The research was guided by the ability-motivation-opportunity theory. This research utilized a descriptive research design and applied the positivist approach. The population of the study included 65 companies listed on the Nairobi Stock Exchange (NSE), and it employed both primary and secondary data, with secondary data consisting of the financial indicator Return on Assets (ROA). Questionnaires were employed to gather primary data, and descriptive and inferential statistics were utilized to analyze the data. The method utilized was linear regression. According to the findings, human resource practices have a beneficial influence on the performance of companies listed on the NSE. This study recommends that the organizations should put mechanisms in place to ensure that all stakeholders are aware of the organizations culture, structure and human reward practices so as to attract the best applicants.

Keywords: HRM practices and performance of firms listed on the Nairobi Securities Exchange (NSE).
Submitted : September 22, 2021

Published : October 14, 2021

ISSN: $2507-1076$

DOI: $10.24018 /$ ejbmr.2021.6.5.1120

M. A. Diriye*

PHD Scholar, Department of Business

Administration, School of Business University of Nairobi, Nairobi, Kenya.

(e-mail: diriye114@gmail.com)

P. K'Obonyo

Ph.D, Lecturer, Department of Business Administration, School of Business -

University of Nairobi, Nairobi, Kenya.

M. Munjuri

Ph.D, Lecturer, Department of Business

Administration, School of Business -

University of Nairobi, Nairobi, Kenya.

G. Wainaina

Ph.D, Lecturer, Department of

Management Science, School of Business

- University of Nairobi, Nairobi, Kenya.

*Corresponding Author

\section{INTRODUCTION}

A human resource configuration represents a collection of interconnected and unchanging human resource practices within the organization related to the exchange [1]. Wasserman and Faust [2] stated that shared human resource design empowers the organization to frame social systems wherein it places individuals and system into specific relationships. This social systems additionally structure an asset for communitarian information management, creation and trade and change of learning. Community-oriented human resource setup portrayed by group incentives, crossutilitarian groups, and such guarantee more prominent reconciliation and more grounded affiliations with the company [3].

McGill and Slocum [4] contend that work structures in learning based associations should be described by porousness and system closeness. A community human resource design gives a sustaining domain that gives help and consolation that teams requirement for employment execution [5]. Cooperative human resource setup makes and encourages believing relations and these believing relationships permit the transmission of more data just as more extravagant and conceivably increasingly significant data. Individuals are probably going to trade touchy data, and they are more averse to fear pioneering behaviour with respect to their partners, empowering a domain of joint effort and trade that can profit the two associations and the people who work inside them [6], [7].

That is, the outlines between useful offices, among workers and clients, and between the organization and its merchants should be obscured (penetrability), and representatives should be kept near one another and near key business forms (arrange closeness). Maybe a standout amongst the ideal approaches to breathe life into penetrability and system closeness is over organizing around teams and systems, particularly cross-practical and joint worker - client critical thinking ones. Fruitful teams can be ready to adjust among self-governance and decentralization of intensity from one perspective, for both inspiration and adaptability and incorporated control then again, for co-appointment [8]. In building up the murkiness for cooperation and coordinated effort, associations may start by reorienting staffing standards to concentrate more on relational abilities and supplement this with group preparing and different cross-useful connections that encourage more extensive learning systems. Development of virtual teams can likewise be a superb way to promote the information sharing procedure. The participatory methodology of human resource design can be mean to create and draw in individuals and associations in functional, innovative jobs as opposed to responsive, and aloof jobs. Also, execution input from friends, clients, 
colleagues, and even subordinates is probably going to encourage learning sharing. Every one of these activities is probably going to expand the limit and open the door for learning trade and blend.

Critical alterations in reasons and culture may necessitate motivating knowledge exchange. In numerous associations, sharing information weakens a person's capacity base; all things considered, solid incentives should be set up to induce common trade. Indeed, even in the best of conditions, a market for learning occurs, and there are a money saving advantage exchange offs in an individual's choice to partake in that showcase. Group motivations, for example, rewards, benefit sharing, and additional sharing may help guarantee that representatives collaborate and trade thoughts with others as their pay relies upon the exhibition of each other. The higher the open doors for community-oriented thinking, the higher are the limit of the association for societal learning and interactive activity. Nahapiet and Ghoshal [9] have appropriately said an alternate type of social capital may go about as an adequate coordination capacity for people or associations to share their insight. Similarly, Kang, Morris, and Snell [10] contended that specific types of social capital might streamline the capacity, prospect, and inspiration for learning allocation crosswise over groups.

The HRM practices can be combined in a way that constitutes a configuration [11]. Integrated framework involving various human resource practices forming a system of HRM configurations has been the focus of human resource managers who have shifted from single human resource practice HRM configurations [12]. Performance of the firm is positively affected by settings of methods compared to an individual HRM practice because the practices in the configurations are interrelated and are consistent internally. Human resource operations are an essential aspect that brings oneness between different human resource practices [13].

According to Subramony [14], there are three sets of HRM configurations, namely skill configurations, motivation, and empowerment configurations. Consistent with Subramony's findings, the chosen practices enhance firm performance because they supplement the knowledge and skills of the employees. Firms should, therefore, make sure that managers possess the required skill in line with the knowledge to effectively execute their managerial functions. They should also make them feel appreciated and provide them with a conducive working environment and structure facilitates the necessary provision and opportunities for them to work. In keeping with the configurational approach, the link between the firm and HRM achievement of goals is in line with intertwined linkages between the performance and outcome practices geared by human resource practices configurations.

\section{RESEARCH PROBLEM}

Actively pursuing human resource management practices ensures that organizations will easily fill senior vacant roles that may arise when the firm expands, when they lose key employees or have promotion opportunities. Human resource management methods, according to Tettey [15], are most effective when they are carried out in a methodical, intentional effort that is guided by a written, organizationwide statement of purpose and policy. According to Waleed
[16], senior executives are acutely aware that the organization's long-term viability is contingent on having the right people in the right locations at the right time. If a successor was suddenly required and none had been selected, the impact on organizational continuity would be disastrous.

Organizations in particular firms operating at NSE have been seen to adopt all the human resource practices while others have adopted none. Some of the practices include high involvement of the employees, commitment maximizers against the cost minimizers, and mass production as opposed flexible production [17]. In addition, the organizations have been seen to have a particular focus on various human resource functions which include development, selection, training, as well as compensation. All these functions and practices have been seen to have an effect on organization performance. Lin [18] saw social capital as a capital like others and contended that social relations are the primary parts of social capital through which significant resources are accessible and open.

Boxall and Purcell [19] states that human resource design empowers the organization to frame social systems wherein it places individuals and system into specific relationships. This social systems additionally structure an asset for communitarian information management, creation and trade and change of learning. According to Schuler and Jackson [20], the organizational characteristics includes organizational culture, organizational structure and communication strategies. Organizational structure influences its actions in two different ways: it facilitates the standard working methods and schedules rest, and it also establishes the people that get the chance to participate where basic leadership processes, and the rate at which their standpoints influence the association's actions [19].

The human resource function can make a crucial contribution in developing the key competencies in the institutions and individual employees that lead to high performance [21]. However, configurations of human resource practices that are adopted by firms without proper strategies have affected robust institutional limitations and lead to deteriorated levels of administrative and proficient uniqueness, and further precisely it has affected performance in highly competitive industries. This is greatly influenced by the organizational structure or governance, which involves those activities in an organization that determines how information flows across the various levels of management [22].

The human resource configurations effectiveness is affected by the weak social capital among most organizations in Kenya, as evidenced by a lack of knowledge sharing and knowledge hoarding. Social capital, by and large, characterized as the real and possible resources installed in affiliations among entertainers, is progressively observed as a huge indicator of the group and organizational execution [23]. Employee approaches and behaviours, high levels of absence and decreased productivity, low quality productions, and inefficiency in service provision are witnessed in companies listed on NSE [24]. Therefore, human resource practices combination must be married with not just the strategic objectives and market orientation of the organization, but also the organizational structure. The NSE 20 increased 21 points or 0.64 percent to 3,357 on Tuesday, 
June 12, 2014, from 3,336 in the earlier transaction period. Historically, the Kenya securities market (NSE 20) grasped an entirely season high of 5,499.64 in March of 2015 and a record low of 2,789.64 in January of 2017.

Many studies have been carried out on human resource configurations. Lee [25] examined the effect of HRM on intellectual capital. The study targeted targeting 777 companies in the Australian biotechnology industry. The study used census sampling to select the sample size. The results showed that human resource configurations were all significantly related to intellectual capital and social capital. This study focused on biotechnology industry thus creating a gap which the current study wishes to fill by targeting firms listed under NSE. Current study will also relate human resource configurations, organizational characteristics and social capital to performance to further fill the gap. A total of 61 companies listed under NSE will form part of the present study.

Studies done by Sarwar et al. [26] in Pakistan on HRM practices and organizational performance. The target population was employees in construction firms in Pakistan. Simple random sampling was used and a sample size of 315 . Findings showed that human resource setup makes an intelligent and aggregate culture inside the association, that support organizational sanity and is emphatically and fundamentally identified with associations dimension of social capital, which is influential for upgrade of association performance. Study by Choudhury [27] was conducted in a developed country whose findings cannot be applicable into the Kenyan context and thus a knowledge gap exists. Current study focuses on firms listed under the Nairobi securities exchange. The study will also target top managers in fims listed under the NSE using census sampling.

The research conducted by Sagwa et al. [28] was focused on two variables, which were human resource management practices and overall performance of employees and thus the findings cannot be used for the comparison with the current study thus creating a knowledge gap that needs to be filled. Current study will be filling this gap by involving other aspects such as organizational characteristics and social capital. Sagwa et al. [28] targeted 60 companies while present study will target 61 companies thus filling the gap on target population.

Sabine [29] assessed human resource configurations, job performance and incentive to carry on working of elder employees in different job types and found that the development configurations and job performance were significantly related to motivation to continue to work. However, they did not centre on the settings of HRM practices, organizational characteristics, and social capital which is the focus of the current study. In addition, the study did not relate the variables to the aspect of performance thus the findings cannot be applied to the current study thus creating a knowledge gap. Therefore, the study strives to fill the research gap by responding to the question - what is the influence of configurations of HRM practices on the performance of firms listed on NSE?

\section{THEORETICAL LITERATURE REVIEW}

This study was based on Ability-Motivation-Opportunity Theory. The proponent of the AMO theory were Bailey [30] which was later reviewed by Appelbaum, Berg, and Kalleberg [31]. The theory has three tenets whish are the ability of an individual, the motivation of the individual, and the opportunity that facilitate participation. The three tenets all culminate into the employee performance that enhances the organization capability to compete with the others [32], [33], [34]. According the theory employees are in a position to perform at their best when they are adequately motivated and provided with an environment that has adequate opportunities where they can have appropriate participation [35], [36].

The AMO theory has been viewed by many researchers as the most useful in explaining the relationship between the human resource management and the organizational performance in various firms around the world [33], [37]. Some researchers have argued that AMO theory effect on the organization performance seem to be complex in that it depends on the occurrence of particular practices in a specific organization. The practices have to be related to the human resource content. In addition the theory is dependent on the how the employee perceive these practices which will have an overall effect on the organization performance [38].

The AMO theory clarifies the affiliation between HRM configurations and organization output. This theory suggests that human resource activities and policies may be applied to be used to impact the person's capability, inspiration and chance to achieve, which contribute to an enhancement of a persons' job act result. The theory has a special focus on the various institutions which forms the context and situations that have an overall effect on the performance of the employee. The theory further enables the managers and the employees perform to their best while making sure they get the required knowledge, skills, as well as the abilities to conduct their respective functions. AMO Theory can be applied to the various organization while utilizing the various human resource configuration and how this will impact on the performance of the company. This theory relates to how social capital affects firms performance.

This theory directs how competencies necessary to the routine of conduct; enthusiasm - the impetus in the direction of a behavior and chance - background and occurrence factors pertinent to the fulfilment of the behavior. Critics of AMO claimed that the theory does not promote a reward arrangement based on employee participation [21]. If suitable rewards can be attached to AMO, then the firm causes the belief amongst the staff that greater efforts and independence will pay off, which fosters employees' readiness to be preemptive in their job performance. Lee [25] further claimed that employees would be unwilling to show inventiveness or autonomy at work if they do not observe that the company is providing them with the possibility of promotion in the whole process. 


\section{CONFIGURATIONS OF Human RESOURCE MANAGEMENT PRACTICES AND ORGANIZATIONAL PERFORMANCE}

Worldwide, competitive business depends on configurations of HRM practices the exclusivity of their human resources and the organizations for handling human resources successfully to improvement good gain. Many firms have shifted from adopting single human resource practices to combinations of methods which form configurations. This shift has been prompted by the empirical evidence that shows that a setting of human resource practices generates greater outcomes on firm performance than the result caused by one single method [39]. The interrelationship, internal consistency, and complementarity of methods within a configuration of HRM practices enhance the motivation of employees and contribute to business output [40]. According to Subramony [14], there are three sets of HRM configurations, namely; skill configurations, motivation configurations, and empowerment configurations.

Commitment maximizers enhance firm performance because they supplement the knowledge and skills of the employees. A diversity of packages of human resource practices have been advanced in the works. At a minimum, three assumptions can be stretched approximately the previous examination. Governments in convinced productions assume moreover an occupied band of human resource performs or practically nobody. They also improve packages that deliver workers with fair points of track and incentives and empowerment. They also enhance packages that enhance the autonomy of the workforce and their accountability levels [14].

The skill enhancement believed to raise obligation contains such human resource practices as enrolment, socialization, and experience. Employee skill enhancement, commitment, and motivation are considered to be fulfilled through human resource configurations. Output-based resources are efficiently used instead of investment human resource practices that include training this has forwarded the goal of cost minimization. Settings of human resource practices have led to a competitive advantage. For successful knowledge management practices, the human resource configurations, which plays a crucial role in developing the knowledge base, must be well aligned [13].

The human resource configuration encompasses precise activities that directly aim to improve intellectual capital or information presentation. Achievement and expansion of services are the two most significant human resource meanings that help surge human capital [41]. Skill-acquire practices emphasize on talent selection and employment. When picking and enlisting, administrations must not only expand the hopeful pool by using a wide diversity of drafting sources to surge the number of contenders partitioned but also wrinkle more evidence about each interviewee to make the engagement procedure more systematic and inclusive. In the calculation, as education is extremely mandatory [42], knowledge-intensive administrations must put precedence on contenders' probable to absorb.

\section{ReSEARCH Methodology}

\section{A. Research Philosophy}

Two different research philosophies in social sciences are the phenomenology and positivism. The phenomenological approach is mainly qualitative and emphases on the direct experience, where the researcher attempts to interpret experiences that are observed in the research phenomenon [43]. Critics of this method contend that it is subjective, lacks sound theoretical foundation and does not relate to the scientific platform of social science research.

The positivist approach is mainly quantitative and valuefree as it separates the researcher from the phenomenon being studied; hence, it is objective [44]. This study adopted the positivist approach because of its quantitative nature, theoretical anchorage and hypothesis testing. Positivism aims at finding causal relationships that explain the patterns of research findings to establish scientific theories [45]. Positivism approach is based on impartiality, neutrality, assessment, and legitimacy of results, thus making it appropriate for adoption in this study.

\section{B. Research Design}

For this study, descriptive research design was used. This is because, hypotheses were tested using data collected from across many organizations/firms at one point in time. The research design intended for this research was descriptive cross-sectional design. Descriptive analysis involves a description of phenomena at that particular time. It allows for the approximations of the sizes of a populace that have similar features and helps in defining the strength or magnitude of the relationship between variables [46].

\section{Population of Study}

The population of this research was 65 companies listed by NSE in Kenya (NSE Handbook) and were studied.

\section{Data Collection}

This study used both primary and secondary data; secondary data included ROA as a financial indicator, and data was gathered from NSE and Capital Markets Authority financial reports. Primary data was gathered using a questionnaire that included a five-point Likert scale for each variable derived from a variety of sources of literature that looked at similar topics. The questionnaire had four sections which contained both open and closed questions. Close ended questions were appropriate for this study as they gave the respondents a chance to choose from the available options. The respondents of the study were top managers from 65 corporations listed by NSE

\section{E. Reliability and Validity Tests}

The degree to which an evaluation tool produces consistent and reliable results is referred to as reliability. Orodho [47] defines the degree to which a particular measurement technique delivers comparable findings over a number of trials. The researcher employed the split-half reliability approach to determine the instrument's reliability. The test was divided into two halves and given to all of the participants in the pilot study, with each half being assessed individually. To assess the reliability, the scores from one half of the test were compared to the scores from the other half. 
The strategy was chosen because assessing dependability with two tests or having two test administrations is impractical or undesirable (because of limited time or money). Cronbach's alpha (0.7) was used to assess the instrument's item dependability.

\section{F. Data Analysis}

Data was analyzed using descriptive and inferential statistics, as well as three types of regressions: basic linear regression, stepwise regression, and multiple regression. However, many tests were performed before to the regression, including normality and linearity, normalcy, multicollinearity, and homogeneity.

\section{RESULTS AND DISCUSSION}

The response rate was 92.3 percent from the 60 respondent who returned the questionnaires out the 65 respondents. This rate of response was satisfactory for the analysis since the response rate of 50 percent is sufficient. It has been suggested that of 60 percent is acceptable, while 70 percent is generally excellent as indicated by the perspectives on Mugenda and Mugenda [46] and Sanders et al. [48].

A. Human Resource Management Practices and the Performance of Companies Listed on Nairobi Securities Exchange

The study's initial aim was to look at the influence of various human resource management setups on the performance of firms listed on the National Stock Exchange (NSE). Different configurations of human resource management methods have little influence on the performance of firms listed on the NSE, according to the assumptions. Respondents were asked to assess their degree of agreement or disagreement with the statements supplied on a Likert scale of one to five, with one indicating no agreement or disagreement, two representing low agreement or disagreement, and three representing high agreement or disagreement, three representing moderate agreement or disagreement, four representing great agreement or disagreement, and five representing very great agreement or disagreement. Before anything else, respondents were asked to rate a variety of skill.

\begin{tabular}{|c|c|c|}
\hline Statements & Mean & $\begin{array}{c}\text { Standard } \\
\text { Deviation }\end{array}$ \\
\hline $\begin{array}{l}\text { Our company has integrated recruitment and } \\
\text { selection that defines ways of attracting and } \\
\text { retaining employees. }\end{array}$ & 1.917 & 0.696 \\
\hline $\begin{array}{l}\text { Our company has a comprehensive training and } \\
\text { development policy that provides training and } \\
\text { development opportunities for employees to } \\
\text { enable them to meet organization goals. }\end{array}$ & 2.950 & 0.964 \\
\hline $\begin{array}{l}\text { Employees are trained in areas that help in } \\
\text { customer relations and career advancement. }\end{array}$ & 3.133 & 1.016 \\
\hline $\begin{array}{l}\text { The initiatives of training and development } \\
\text { adopted are centered on the development of } \\
\text { employees' skills and competencies in their jobs. }\end{array}$ & 3.283 & 1.027 \\
\hline $\begin{array}{l}\text { Highly skilled employees who can help the } \\
\text { company achieve the objectives are acquired } \\
\text { during the recruitment process. }\end{array}$ & 3.617 & 0.922 \\
\hline Average Mean & 2.980 & \\
\hline
\end{tabular}

As Table I above shows, most of the respondents indicated to a great extent that highly skilled employees who can help the company achieve the objectives are acquired during the recruitment process $($ mean $=3.62$; standard deviation $=0.92)$; The initiatives of training and development adopted are centered on the development of employees' skills and competencies in their jobs. (mean $=3.28$; standard deviation $=0.92$ ) and that employees are trained in areas that help in customer relations and career advancement (mean $=3.13$; standard deviation $=1.02$ ). In addition, respondents indicated to a moderate extent that their company has a comprehensive training and development policy that provides training and development opportunities for employees to enable them to meet organization goals $($ mean $=2.95 ;$ standard deviation $=$ 0.96) and that their company has integrated recruitment and selection that defines ways of attracting and retaining employees $($ mean $=1.92$; standard deviation $=0.70)$. This implies that firms listed at NSE, highly skilled employees who can help the company achieve the objectives are acquired during the recruitment process, The initiatives of training and development adopted are centered on the development of employees' skills and competencies in their jobs. and that employees are trained in areas that help in customer relations and career advancement.

Regarding motivation configurations, respondents gave their responses to several statements and Table II gives the mean scores and corresponding standard deviations.

TABLE II: MOTIVATION CONFIGURATIONS

\begin{tabular}{lcc}
\multicolumn{1}{c}{ Statements } & Mean & $\begin{array}{c}\text { Standard } \\
\text { Deviation }\end{array}$ \\
\hline $\begin{array}{l}\text { Our company has a reward management } \\
\text { policy that enhances employee's performance }\end{array}$ & 3.083 & 1.013 \\
$\begin{array}{l}\text { Our company's incentive and compensation } \\
\text { programs help to increase employee } \\
\text { motivation and retention, which in turn helps }\end{array}$ & 3.617 & 0.804 \\
to drive organizational performance \\
$\begin{array}{l}\text { The rewards and compensation provided is } \\
\text { competitive }\end{array}$ & 3.783 & 0.804 \\
$\begin{array}{l}\text { Our company offers financial and non- } \\
\text { financial rewards that enhance employee } \\
\text { performance }\end{array}$ & 4.150 & 0.515 \\
\hline Average & & \\
\hline
\end{tabular}

Based on the findings in Table II above, majority of the respondents indicated to a great extent that their company offers financial and non-financial rewards that enhance employee performance $($ mean $=4.15$; standard deviation $=$ 0.52 ), the rewards and compensation provided was competitive $($ mean $=3.78$; standard deviation $=0.80)$ and that Our company's incentive and compensation programs help to increase employee motivation and retention, which in turn helps to drive organizational performance $($ mean $=3.62$; standard deviation $=0.80$ ). Further, respondents indicated to a moderate extent that company has a reward management policy that enhances employee's performance ( mean $=3.08$; standard deviation $=1.01$ ). This implied that firms listed at NSE offered financial and non-financial rewards that enhance employee performance, the rewards and compensation provided is competitive and that Our company's incentive and compensation programs help to increase employee motivation and retention, which in turn helps to drive organizational performance. 
Lastly, the respondents were asked to rate statements on empowerment configurations and the mean scores, and standard deviation values are presented in Table III below.

\begin{tabular}{lcc}
\multicolumn{3}{c}{ TABLE III: EMPOWERMENT CONFIGURATIONS } \\
\hline \multicolumn{1}{c}{ Statements } & Mean & $\begin{array}{c}\text { Standard } \\
\text { Deviation }\end{array}$ \\
\hline $\begin{array}{l}\text { Performance appraisal at our company is } \\
\text { believed to be able to satisfy and motivate } \\
\text { employees to perform better. }\end{array}$ & 3.200 & 0.860 \\
$\begin{array}{l}\text { All managers at our company participate in } \\
\text { the appraisal process. }\end{array}$ & 3.767 & 0.810 \\
$\begin{array}{l}\text { Our company undertake regular } \\
\text { performance appraisal. } \\
\text { There is an increment in pay resulting from } \\
\text { excellent appraisal results. } \\
\text { Performance evaluation serves on the basis } \\
\text { promotion. }\end{array}$ & 3.533 & 0.999 \\
\hline Average & 3.333 & 0.752 \\
\hline
\end{tabular}

As Table III above shows, majority of the respondents indicated to a great extent that all managers at their company participate in the appraisal process (mean $=3.77$; standard deviation $=0.81$ ), their company undertake regular performance appraisal (mean $=3.53$; standard deviation $=$ 1.00 ) and that there was an increment in pay resulting from excellent appraisal results (mean $=3.48$; standard deviation $=$ 1.20). Further, respondents indicated to a moderate extent that performance evaluation serves on the basis promotion (mean $=3.33$; standard deviation $=0.75$ ), and that performance appraisal at our company was believed to be able to satisfy and motivate employees to perform better ( mean $=3.20$; standard deviation $=0.86$ ). This was an indication that all managers at companies listed at NSE participate in the appraisal process, companies listed at NSE undertake regular performance appraisal and that there was an increment in pay resulting from excellent appraisal results.

\section{B. Hypothesis Testing}

In order to test the which was that HRM practices does not influence performance of firms listed on NSE, simple linear regression was done and the results are as shown in Table IV below.

TABLE IV: REGRESSION RESULTS FOR THE EFFECT OF CONFIGURATION OF HuMAN RESOURCE PRACTICES ON PERFORMANCE

\begin{tabular}{|c|c|c|c|c|c|}
\hline & \multicolumn{5}{|c|}{ Model Summary } \\
\hline Model & $\mathrm{R}$ & \multicolumn{3}{|c|}{ R Square } & $\begin{array}{c}\text { Adjusted R } \\
\text { Square }\end{array}$ \\
\hline \multirow[t]{3}{*}{1} & 0.467 & \multicolumn{2}{|r|}{0.218} & \multicolumn{2}{|r|}{0.212} \\
\hline & \multicolumn{5}{|c|}{ ANOVA } \\
\hline & Model & $\begin{array}{l}\text { Sum of } \\
\text { Squares }\end{array}$ & df & $\begin{array}{c}\text { Mean } \\
\text { Square }\end{array}$ & F Sig. \\
\hline \multirow{3}{*}{1} & Regression & 1.936 & 1 & \multirow{3}{*}{$\begin{array}{l}1.936 \\
0.207\end{array}$} & \multirow[t]{3}{*}{9.2710 .003} \\
\hline & Residual & 12.006 & 58 & & \\
\hline & \multirow[t]{2}{*}{ Total } & 13.942 & 59 & & \\
\hline \multicolumn{5}{|c|}{ Coefficients } & \\
\hline \multirow{2}{*}{\multicolumn{2}{|c|}{ Model }} & $\begin{array}{l}\text { Unstandardized } \\
\text { Coefficients }\end{array}$ & $\begin{array}{c}\text { Standardized } \\
\text { Coefficients }\end{array}$ & $\mathrm{t}$ & \multirow[t]{2}{*}{ Sig. } \\
\hline & & $\mathrm{B}$ & Beta & & \\
\hline \multirow{2}{*}{1} & (Constant) & 1.85 & & 5.415 & \multirow{2}{*}{$\begin{array}{l}0.000 \\
0.000\end{array}$} \\
\hline & CHRM & 0.494 & 0.467 & 6.307 & \\
\hline
\end{tabular}

The results in Table IV above show that $\mathrm{R}^{2}$ was 0.218 an indication that the explanatory power of configuration of HRM practices on organization performance was low implying that 21.8 percent of variation in performance was attributable to configuration of human resource practices while 78.2 percent of changes in organization performance explained by factors other than configuration of human resource practices. However, the overall model was significant since p-value of 0.03 was less than 0.05 level of significance, therefore, the null hypothesis that configuration of HRM practices does not influence performance of firms listed on NSE was rejected and the alternative hypothesis that configuration of HRM practices influence performance of firms listed on NSE was supported.

Regarding individual significance, both the constant and configuration of human resource practices were significant since the p-values were less than 0.05 level of significance. The predictive equation was $\mathrm{P}=1.85+0.494 \mathrm{CHRM}$ meaning that if the configuration of HRM practices goes up by one unit, performance of firms listed at NSE will, on average go up by 0.494 units.

\section{Discussion of Findings}

The results showed that configurations of HRM practices had a significant effect on performance of companies listed on NSE. These results are in line with previous studies that posit that the human resource configuration encompasses precise activities that directly aim to improve intellectual capital or information presentation. Achievement and expansion of services are the two most significant human resource meanings that help surge human capital [41]. Skillacquire practices emphasize on talent selection and employment. When picking and enlisting, administrations must not only expand the hopeful pool by using a wide diversity of drafting sources to surge the number of contenders partitioned but also wrinkle more evidence about each interviewee to make the engagement procedure more systematic and inclusive. In the calculation, as education is extremely mandatory [42], knowledge-intensive administrations must put precedence on contenders' probable to absorb.

\section{CONCLUSION AND RECOMMENDATIONS}

The study concludes that at firms listed at NSE, highly skilled employees who can help the company achieve the objectives are acquired during the recruitment process, The initiatives of training and development adopted are centered on the development of employees' skills and competencies in their jobs. and that employees are trained in areas that help in customer relations and career advancement. In addition, the study concludes that firms listed at NSE offers financial and non-financial rewards that enhance employee performance, the rewards and compensation provided is competitive and that Our company's incentive and compensation programs help to increase employee motivation and retention, which in turn helps to drive organizational performance. Further, the study concludes that all managers at companies listed at NSE participate in the appraisal process, companies listed at NSE undertake regular performance appraisal and that there is an increment in pay resulting from excellent appraisal results.

The recommendation is that the organization should continue with its efforts to enhance their performance. The 
study further recommends that more sensitization should be done in the area of on-the-job training, so as to promote efficiency and effectiveness in the management of procedures in the organization.

There is a need for the organization to reassess its pay structure through and find other ways of motivating employees such as performance incentives and benefits. Finally, the company should have a 'global outlook'. Businesses of all sizes across the globe can interact and share information, technology and how reward processes are applied.

\section{A. Suggestions for Further Study}

The study did not examine how human resource management techniques may be continuously improved, and it is therefore advised that additional research be conducted to address this issue. It is also advised that further research on the same subject be conducted, with the scope of the study being broadened to include other human resource management methods that were not included in the current study. Since the study focused on publicly traded companies on the Nairobi Stock Exchange, it is necessary to do similar studies on non-publicly traded companies on the Nairobi Stock Exchange in Kenya.

\section{REFERENCES}

[1] I. Tadić \& S. Pivac, "Defining human resources "bundles" and Its' correlation with companies' financial performances," International Journal of Economics and Management Engineering, vol. 8(4), pp. 1032-1036, 2014.

[2] S. Wasserman, \& K. Faust, "Social network analysis: Methods and applications", 1994.

[3] J. E. Mathieu, S. I. Tannenbaum, \& E. Salas, "Influences of individual and situational characteristics on measures of training effectiveness,' Academy of management journal, vol. 35, no. 4, pp. 828-847, 1992.

[4] M. E. McGill, \& J. W. Slocum, "The smarter organization: How to build a business that learns and adapts to marketplace needs," John Wiley \& Sons, 1994.

[5] J. S. Margulies \& B. H. Kleiner, "New designs of work groups: applications of empowerment," Empowerment in Organizations, 1995

[6] J. L. Bradach \& R. G. Eccles, „Price, authority, and trust: From ideal types to plural forms," Annual review of sociology, vol, 15, no. 1, pp. 97-118, 1989.

[7] D. M. Rousseau, S. B. Sitkin, R. S. Burt, \& C. Camerer, "Not so different after all: A cross-discipline view of trust," Academy of management review, vol. 23, no. 3, pp. 393-404, 1998.

[8] J. E. McGrath \& L. Argote, "Group processes in organizational contexts," Blackwell handbook of social psychology: Group processes, 603-627, 2001

[9] J. Nahapiet, \& S. Ghoshal, "Social capital, intellectual capital, and the organizational advantage,' Academy of management review, vol. 23, no. 2, pp. 242-266, 2008.

[10] S. C. Kang, S. S. Morris, \& S. A. Snell, "Relational archetypes, organizational learning, and value creation: Extending the human resource architecture," Academy of management review, vol. 32, no. 1, pp. 236-256, 2007.

[11] M. Makhija, "Comparing the resource-based and market-based views of the firm: empirical evidence from privatization," Strategic management journal, vol. 24, no. 5, pp. 433-451, 2003.

[12] S. Mayson \& R. Barrett, "The science and practice of HRM in small firms," Human Resource Management Review, vol. 16, no. 4, pp. 447 455, 2006.

[13] D. Nickson, "Human resource management for hospitality, tourism and events, " Routledge, 2013.

[14] M. Subramony, "A meta-analytic investigation of the relationship between firm bundles and firm performance," Human Resource Management, vol. 48, no. 5, pp. 745-768, 2009.

[15] W. J. Tettey, "Regenerating scholarly capacity through diaspora engagement: the case of a Ghana diaspora knowledge network," In Diasporas, Development and Governance (pp. 171-186). Springer, Cham, 2016.
[16] A. Waleed, "The Relationship Between Human Resource Practices and Employee Retention In Public Organization: An Exploratory Study Conducted In The United Arab Emirates," Unpublished Thesis, Edith Cowan University, 2011.

[17] S. M. Toh, F. P. Morgeson, M. A. Campion, "Human resource configurations: investigating fit with the organizational context," Journal of Applied Psychology, vol. 93, no. 4, p. 864, 2008.

[18] N. Lin, Social capital: A theory of social structure and action, Vol. 19, Cambridge university press, 2002.

[19] P. Boxall \& J. Purcell, "Strategy and human resource management," Macmillan International Higher Education, 2008.

[20] R. S. Schuler \& S. E. Jackson, „A quarter-century review of human resource management in the US: The growth in importance of the international perspective," Management revue, pp. 11-35, 2005.

[21] D. E. Guest, "Human resource management and performance: still searching for some answers," Human resource management journal, vol. 21, no. 1, pp. 3-13, 2011.

[22] M. Alvesson, "Critical leadership studies: The case for critical performativity," Human Relations, vol. 65, no. 3, pp. 367-390, 2012.

[23] P. S. Adler, S. W. Kwon, "Social capital: Prospects for a new concept," Academy of Management Review, vol. 27, no. 1, pp. 17-40, 2002.

[24] M. W. Mwaniki, "Modelling the Impacts of Predicted Environmental Change on the Frequency and Magnitude of Rainfall-Induced Landslides in Central Kenya," 2016.

[25] C. Lee, "How does HRM enhance strategic capabilities? Evidence from the Korean management consulting industry," The International Journal of Human Resource Management, vol. 2, no. 1, pp. 126-146, 2012.

[26] H. Sarwar, B. Khan, K. Nadeem, and J. Aftab, "Human Capital HRM Practices and Organizational Performance In Pakistani Construction Organizations: The Mediating Role of Innovation," Business research, vol. 4, no. 6, pp. 23-45, 2016.

[27] P. K. Choudhury, "Role of private sector in medical education and human resource development for health in India," Institute for Studies in Industrial Development, 2014.

[28] E. V. Sagwa, P. K’Obonyo, M. Ogutu, “Human Resource Management Practices and Performance of Firms Listed on the Nairobi Securities Exchange," 2015.

[29] M. A. Sabine, "Human resource configurations: investigating fit with the organizational context," Journal of Applied Psychology, vol. 93, no. 4, p. 864, 2010.

[30] T. Bailey, "Discretionary effort and the organization of work: Employee participation and work reform since Hawthorne," Teachers College and Conservation of Human Resources, Columbia University, 1993.

[31] E. Appelbaum, T. Bailey, P. Berg, A. L. Kalleberg, "Manufacturing advantage: Why high-performance work systems pay off," London: ILR Press, 2000.

[32] A. C. Claudia, "Hrm - Well-Being At Work Relation. A Case Study," Annals - Economy Series, vol. 4, pp. 140-145, 2015.

[33] E. Knies, P. Leisink, "Linking people management and extra-role behaviour: results of a longitudinal study," Human Resource Management Journal, vol. 24, np. 1, pp. 57-76, 2014.

[34] A. Munteanu, "What Means High Performance Work Practices for Human Practices - Performance Relationship: Testing a Three Pathways Amo Model," Academy of Management Annual Meeting Proceedings, (M), pp. 1201-1206, 2014.

[35] J.-H. Choi, "The HR-performance link using two differently measured HR practices," Asia Pacific Journal of Human Resources, vol. 52, no. 3, pp. 370-387, 2014.

[36] J. A. Marin-Garcia, "What do we know about the relationship between High Involvement Work Practices and Performance?" WPOMWorking Papers on Operations Management, vol. 4, no. 2, pp. 01-15, 2013.

[37] A.-L. Demortier, N. Delobbe, A. El Akremi, "Opening the Black Box of Hr Practices - Performance Relationship: Testing a Three Pathways Amo Model," Academy of Management Annual Meeting Proceedings, (M), pp. 1201-1206, 2014.

[38] M. Ehrnrooth, I. Björkman, "An integrative HRM process theorization: Beyond signalling effects and mutual gains," Journal of Management Studies, vol. 49, no. 6, pp. 1109-1135, 2012.

[39] C. Chadwick, "Theoretical insights on the nature of performance synergies in human resource: Toward greater precision," Human Resource Management, vol. 20, pp. 85-101, 2010.

[40] I. Tadić, S. Pivac, "Defining human resources "bundles" and Its" correlation with companies' financial performances," International Journal of Social, Management, Economics and Business Engineering, vol. 8, no. 4, pp. 999-1003, 2014. 
[41] N. W. Hatch, J. H. Dyer, "Human capital and learning as a source of sustainable competitive advantage," Strategic management journal, vol. 25, no. 12, pp. 1155-1178, 2004.

[42] C. C. Chan, B. Scott-Ladd, "Organisational learning: Some considerations for human resource practitioners," Asia Pacific journal of human resources, vol. 42, no. 3, pp. 336-347, 2004.

[43] D. Cooper, P. Schindler, "International Edition: Business Research Methods.; New Delhi; MacGraw-Hill," Bulletin. District Development Report,(2007). Ministry of Planning, Murang'a District, Kenya government District Development reports issue Bulletin, 2008.

[44] M. Easterby-Smith, S. Li, J. Bartunek, "Research methods for organizational learning: The transatlantic gap," Management Learning, vol. 40, no. 4, pp. 439-447, 2002.

[45] C. Robson, "How to do a research project: a guide for undergraduate students, "Wiley Global Education, 2014.

[46] O. Mugenda, A. Mugenda, "Research methods: quantitative and qualitative approaches," 2003.

[47] J. A. Orodho, "Techniques of writing research proposals and reports in education and social sciences," Nairobi: Masola Publishers, 2004.

[48] L. D. Sanders, "Discovering research methods in Psychology: A student's guide," John Wiley \& Sons, 2010.

[49] Resources in an organization. Annals of the University of Petrosani, Economics, vol. 14, no. 1, pp. 243-250. 